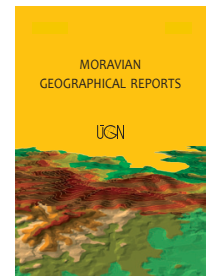

\title{
"Tell me where you shop, and I will tell you who you are": Czech shopper profiles according to traditional, large-scale and alternative retail options
}

\author{
Jana SPILKOVÁ a *
}

\begin{abstract}
Traditional, 'post-traditional' large-scale, and 'alternative' food shopping options are used in this paper to address the following questions: Who are the customers of these different retail formats? Is it possible to discern certain types of shopper according to retail formats? Do alternative food networks attract significantly different consumers than traditional forms and large-scale outlets? Relatively unique data collected in an omnibus survey by The Centre for Independent Public Opinion Research during 2014, 2015 and 2017 $(n=3,168)$ are used in this analysis. The consumption habits and preferences of a representative sample of the Czech population were subject to investigation. Results are presented mainly by descriptive statistics and the testing of hypotheses on the similarity or difference of given shopper populations by contingency analysis (associations between characteristics use contingency coefficients). A profile of shoppers according to food provisioning options is presented, and demographic, socio-economic and geographic factors influencing current trends in the shopping behaviours of Czech consumers are analysed. Significant differences between the customers of diverse retail formats and alternative possibilities to acquire food are among the most important distinguishing factors characterising Czech shoppers today.
\end{abstract}

Keywords: retail formats, alternative food networks, shopper profiles, Czech Republic

Article history: Received 19 September 2017; Accepted 27 March 2018; Published 30 September 2018

\section{Introduction}

Shopping habits and shopping behaviours are already established topics in the social geographic field focusing on retail environments (Golledge and Stimson, 1997; Kunc et al., 2013; Miller et al., 1998; Spilková, 2012a, etc.). Consumption choices and the spatial behaviours of particular shoppers help to organise the net of retail facilities in a way which reflects consumers' wishes and preferences, and thus balances the demand and supply side of retailing logic within shopping spaces. General changes in retailing, as well as many new trends coming from abroad or imposed by globalisation pressures, have formed customers' perspectives and behaviours in either positive or negative manners (Spilková, 2011, 2012b). The dynamics of shopping behaviour is especially interesting to study in the so-called "transition" countries (post-socialist countries of Central and Eastern Europe), where 'catching up' with the developed world in terms of quantity, concentration and lately also in terms of the quality aspects of retailing, has occurred over the last twenty-five years.
The history of Czech retailing is a history of a journey from a centrally planned economy to the installation of a market system at the beginning of the 1990s. The arrival of international retail chains in the Czech Republic and their large-scale retail concepts at that time were a "dream come true" for most Czech customers, who had mainly experienced very limited shopping opportunities during the socialist era. Czechs started to prefer large-scale retail formats (such as hypermarkets, supermarkets, discount stores and shopping malls) to traditional smaller retail facilities (Maryáš et al., 2014; Spilková, 2008). Hypermarkets are now the primary shopping place for food for almost one half $(48 \%)$ of Czech households, followed by discount stores (24\%) and supermarkets (17\%: GfK, 2016). Modern, largescale facilities with $400 \mathrm{~m}^{2}$ or more then concentrate $80 \%$ of the total sales in food and convenience goods, which certainly represents the highest share in Central Europe (Hospodářské noviny, 2016). After two decades of dominance of these retail formats, however, some initial problems have appeared, related mainly to the retail environments

\footnotetext{
${ }^{a}$ Department of Social Geography and Regional Development, Faculty of Science, Charles University Prague, Czech Republic (*corresponding author. J. Spilková, e-mail: spilkova@natur.cuni.cz)
} 
in these outlets, the quality of goods on sale and some retailers' practices. It seems that Czech shoppers have started a counter trend to this "big box supremacy": namely, dissatisfied customers, who are looking for more intimate ways of shopping and caring more about the goods they buy with respect to their nutrition values, provenance, context of production, etc., have welcomed the first alternative food networks in the Czech Republic (Spilková, 2016). As such alternatives, farmers' markets appeared in 2009-2010, followed by farmer's shops, box schemes, communitysupported agriculture and later, community gardens. These alternatives were keenly embraced by consumers across age groups and social strata (Spilková et al., 2013). Despite their popularity, however, they still represent only a small portion of total food sales (estimates range from 5-10\%).

This paper addresses the following questions: Who are the customers in these different retail formats? Is it possible to discern certain types of shoppers according to retail formats in the Czech shopping-scape? Do alternative food networks attract significantly different consumers than traditional forms and large-scale outlets? In pursuing these questions, I make use of unique data sets collected in omnibus surveys by The Centre for Independent Public Opinion Research (CVVM) of the Institute of Sociology of the Czech Academy of Sciences, over the periods 2014, 2015 and 2017, with a total sample size of 3,168 . The surveys questioned the consumption habits and preferences of a representative sample of the Czech population, among other topics. Our goal is two-fold:

i. to present a profile of shoppers according to the number of food provisioning options: traditional (smaller selfservice shops, convenience shops, small counter shops); large-scale (hypermarket, supermarket, discount); and alternative (farmers' markets, box schemes, farm gate, farm shop, etc.); and

ii. to analyse the demographic, socio-economic and geographic factors influencing current trends in the shopping behaviours of Czech consumers.

After an overview theoretical background focusing on shopper typologies and geo-marketing, the data sources and methodology used in this analysis are presented. Results are discussed in the next section, followed by a summary and some concluding remarks.

\section{Theoretical background: Shopper segmentation and geodemography}

Marketing theorists are fond of diverse shopper typologies, behavioural segmentations of shoppers, motivational or search studies, consumer patronage research, etc. (Sinha and Uniyal, 2005). The shopper typologies emerged during the $1950 \mathrm{~s}$ as a reaction to the dramatic transformation which shopping had undergone in the USA and Western Europe when entering the phase of mass consumption. Classifications of shoppers have developed ever since and have involved increasingly complex approaches based on evolving knowledge of marketing, sociology, psychology, behavioural science, geography, demography, media studies, etc.

\subsection{General shopper typologies}

One of the first shopper typologies was published by Stone (1954), who in his seminal work identified four shopper types: economic (price driven); personalising (preferring personal contacts); ethical (with a clear ethical standpoint); and apathetic. An interesting typology was later presented by Kotler (1965), who suggested Marshallian shoppers (economically rational), Freudian shoppers (fantasy driven), Pavlovian shoppers (stimulus prone), Hobbesian shoppers (organisationally based) and Veblenian shoppers (peer group status influenced). In comparison, Stephenson and Willett (1969) proposed four types of shoppers: convenience; recreational; price bargain; and loyal. Subsequently, Johnston presented a 'self-explanatory' typology of pragmatic shoppers, satisfied shoppers, shopping trippers and bargain hunters (Johnston, 1974, in O'Brien and Harris, 2013). During the 1970s, a number of shopper typologies focusing only on female shoppers emerged (Darden and Reynolds, 1971; Darden and Ashton, 1975; Moschis, 1976, Williams et al., 1978, etc.).

Another typology stemming from a comprehensive sample which included both men and women is that of Lesser and Hughes (1986), which has a seven-fold schema: inactive (not interested in shopping); active (interested, like shopping); service (demanding good customer service and friendly personnel); traditional (active people, who do not embrace shopping, but have to shop from time to time); dedicated fringe (want to be different, information seeking, novelty seeking); price (bargain seekers); transitional (usually at the beginning of a family cycle, thus caring for health and life style, but already creating specific shopping habits); convenience (aim to shop easily, do not care about price or service); coupon saver (shopping planned on the basis of action, sales etc.); innovator (impulsive shoppers, looking for new products, status oriented); and unclassified shoppers. Other attempts to develop a typology of shoppers followed (Cullen, 1990; Jarratt, 1996, etc.), but these generally involved all the types and categories already indicated above, generally based on attitudes towards shopping or shopping motives in general terms.

As well as the shopper typologies created from attitudes to shopping and psychographics, there are some typologies created for a specific type of shopping venue, which is an approach closer to the understanding of shopper classification in this paper. As explained further, the retail options assessed in this paper are based on the formulation of questions and their possible responses within the omnibus survey used for the analysis. Traditional, large-scale and alternative provisioning options are considered. The traditional retail options include smaller self-service shops, convenience shops and small counter shops, understood in general as retail facilities smaller than $400 \mathrm{~m}^{2}$ with a wide assortment of miscellaneous goods serving daily needs. Large-scale retail outlets are comprised of hypermarkets, supermarkets and discount stores. Hypermarkets are, by definition, single-story outlets with a sales area greater than $2,500 \mathrm{~m}^{2}$ and with a full assortment of foods and a wide assortment of non-food goods. Supermarkets are defined as retail outlets with a complex assortment of food items and a complementary assortment of non-food goods, with sales area between $400 \mathrm{~m}^{2}$ and 2,500 $\mathrm{m}^{2}$. Discount stores are retail units of about 400 to $1,000 \mathrm{~m}^{2}$ of sales area, with a limited assortment of goods and a very quick turnover and high demand frequency, often with a lower quality of the retail/ built environment, which is, on the other hand, outweighed by the lower prices (Spilková, 2012b). Alternative options proceed from the definition of alternative food networks as new alliances between consumers and producers, creating experimental spaces of new food provisioning practices (Roep and Wiskerke, 2012): the various formats (farmers' markets, box schemes, farm gate, farm shop, etc.) are explained in Spilková (2016). 
Finn et al. (1994) conducted their research in the environment of a large shopping mall and identified five groups of mall-shoppers: light consumers, who came with a clear purpose to buy a particular item; multiple shoppers who planned to shop for more items in more outlets; leisure shoppers who came to the mall mostly for recreation and entertainment; social users who made use of the mall to meet others for coffee or a drink; and combined purpose consumers, i.e. those who had several of the previously-mentioned reasons to visit the mall. Mall shoppers have also been studied by Bloch et al. (1994), whose categories were: mall enthusiasts, who liked to be involved in many activities in the mall including purchasing, services, entertainment etc.; traditionalists, who also engage in many mall-based activities, but primarily focus on shopping and services; grazers, who spend most of their time in the mall eating and observing other shoppers; and the minimalists, who tend to avoid shopping in the mall if at all possible, consider it a loss of time and are uninvolved in the majority of mall activities.

\subsection{Shoppers in alternative food networks}

Alternative food networks have also already attracted researchers' interests. Rather than a true typology, these works depict a "typical shopper" in these retail forms and describe some basic demographic and socioeconomic characteristics. Lydia Zepeda (2009) based her characteristics of a farmers' market shopper on knowledge and research in various markets across the United States. According to her research, a typical farmers' market shopper is female, motivated by freshness and nutritional value, less sensitive to price, enjoys cooking in general and is often involved in other alternatives to traditional shopping (organic, fair trade, ethnic, cooperative). Baker et al. (2009) produced similar results: typical consumers at the farmers' market were female, in their early 50 s, with an annual household income of over $\$ 60,000$. A common problem often mentioned in foreign literature regarding alternative food networks and their customers is their possible social exclusivity, i.e. the fact they might attract predominantly white, younger, middle- and upper- class urban professionals (Conner et al., 2010; Freidberg, 2004; Morgan, 2010). Similar research conducted at Czech farmers' markets during the first year of their functioning (Spilková et al., 2013), however, found no evidence of such signs of social exclusivity, revealing instead customers of different ages (including many pensioners), and wide-ranging educational and economic backgrounds, all motivated by the pursuit of freshness and taste.

In fact, the typology of farmers' market customers is not a straightforward research task, since individual characteristics alone do not serve as good proxies for determining behaviours. A combination of demographic, socioeconomic and lifestyle characteristics make up a typical farmers' market shopper, and contextual differences unique to a given community also play a role. Byker et al. (2012) tried to sum up existing knowledge about farmers' market shoppers in the US by looking at wide-ranging research on the topic. They concluded that farmers' market patrons are more likely to be female, although this might be affected by the fact that most men tend to refer primary food shopping and cooking responsibilities to women - rather than because they shop at other food-selling formats. The age of farmers' market shoppers, according to these studies, was slightly higher (40 years and over). With respect to income, the results were inconclusive: some studies found higher income categories, while others found shoppers with incomes lower than expected. This suggests that willingness and motivation to pay for food at the market is a better predictor than income alone and that the consumers value also the non-monetary aspects of the markets. Byker et al. (2012) determined that education was the best predictor of farmers' market (and other direct-market) shoppers, stating that most studies confirmed that these retail forms attract highly-educated individuals (college and higher education).

Nevertheless, it is obvious that studies focusing on motivations to shop at farmers' markets, rather than consumer demographics, prevail in Western academia. Carey et al. (2011) created a typology of farmers' market shoppers in Scotland based on motivations, revealing that freshness, a passion for cooking and the nutritional value of the products on sale being the most important factors, followed by environmental motivations and support for local farmers. Canadian shoppers (Feagan and Morris, 2009) also highly valued the freshness of produce at farmers' markets, and also mentioned factors such as support to local farmers, a healthy diet, social interaction and community life. Byker et al. (2012) also list motivational factors of US shoppers as fresh food, high quality, supporting local agriculture and the social appeal of farmers' markets. As well, Elepua and Mazzocco (2010) created a typology of farmers' market shoppers, identifying five groups differing significantly in demographic characteristics and behavioural attributes: market enthusiasts, recreational shoppers, serious shoppers, low-involved shoppers and basic shoppers.

As a representative of "other-than-farmers' market" alternatives, a unique typology of box schemes' shoppers in the Czech Republic by Unčovská (2011) was inspired by Mary Douglas's Cultural Theory. Three groups of box scheme buyers were identified: "biomaximalists" (those who try to cover all the household's needs with organic products); "bioseekers" (organic vegetables are the base and are complemented by other different products, becoming increasingly involved in sustainable consumption habits); the last group are "bioboxers" (buying only the organic box from a box scheme, not interested in other alternative food options). It is interesting that most of the respondents were also women. In another study of box schemes, despite the lack of coherent demographic or social structure studies, Spilková and Šifta (2016) found a heterogeneous group of buyers (organic seeking mothers, status-seeking gourmands, etc.) who, however, tend to be more interested and involved in sustainable consumption. The available Czech and foreign research reports suggest that box scheme customers tend to be individuals and families with higher incomes (Thom and Conradie, 2013; Seyfang, 2003; inter alia).

\subsection{Geodemographic systems}

It is obvious that the choice of shopping place is impacted by a multidimensional matrix of factors on the level of an individual (demographic characteristics, socio-economic profile, behavioural aspects, life style, etc.), community (social and non-monetary benefits), and on a wider political range (support for local farmers, the animal welfare movement, sustainable consumption, etc.). Shoppers of some particular retail formats cannot be categorised on the basis of a simplified and summarised general model (Kunc et al., 2016). From the preceding review, it is also clear that there is insufficient research on the geodemographic characteristics of alternative food network shoppers, and even fewer studies which take into consideration the localities in which retail facilities are located. It is known from the literature, however, that contextual and situational influences affect shoppers' behaviours (Sinha 
and Uniyal, 2005) and diversify the consumer base of various retail formats (Byker et al., 2012). It is therefore also necessary to introduce the approach of geodemography and geodemographic systems, the relevance of which has increased with the transition from a centrally-planned to a market economy with an increasing spectrum of market segments and consumer lifestyles. Geographers play an important role in this situation by creating spatially-defined segmentation schemes, which help retailers to know who their customers are and where they live, as well as which products or services they demand (Spilková, 2012b).

A geodemographic system can be defined as one which helps the retailers' decision-making processes. It is an information technology, assisting the retailers to predict the reactions of their customers, based on statistical models of the latter's identity and residence (Goss, 1995). Geodemographic practice within retail expertise (sometimes also labelled as "geo-marketing") gathers spatial data about consumers, constructs statistical models of their identity, and maps the distribution of their characteristics and shopper types. This process combines large electronic databases, geographical information systems and shopper typologies. Geodemographic systems usually (Spilková, 2012b) comprise data about geography (place of residence, region, area, population, etc.), demography (age, gender, family status, education, religion, income, etc.), psychography (lifestyle, values, personal traits, etc.) and consumer behaviours (attitudes to shopping, loyalty, experience, price sensitivity, etc.).

One critic of geodemographic systems, Jon Goss (1995), points out that these approaches are prone to using simplifying assumptions: first, that the identity of a consumer can be reduced to a file of measurable demographic and psychosocial characteristics to create a complex shopper typology; second, that a shopper's identity predicts their behaviour and consumption patterns, thus, based on their segmentation position, it can be assumed what their behaviours in other aspects of consumer behaviour will be; and third, they suggest that residential location is a determining factor of identity and behaviour, stemming from a generally recognised fact that similar people with similar lifestyles "cluster" within the same localities. It is evident that geodemographics present a substantial reduction of reality. On the other hand, this approach aims to explain consumer patronage and behaviours by a combination of both "subjective" (individual, behavioural, psychological) and "objective" (areal) variables within a given geographical area and settlement system context, and it also has many supporters among both practitioners and scholars.

\section{Data and methods}

This paper is based on an analysis of a unique data source gathered during three waves of an omnibus survey realised in the project: "Socio-geographical indicators reflecting attitudes of the Czech population: database acquisition" by the Center of Independent Public Opinion Research (CVVM in Czech). Representative samples of the Czech population 18 years of age and older were reached (1,076 in 2014, 1,013 in 2015 and 1,079 in 2017). The survey used quota sampling methods, with the following stratification factors: NUTS 3 regions, population size, gender, age and education. The survey was conducted through direct interviews using a paper questionnaire ("PAPI": paper and pen interview method). The omnibus character of the survey meant that a different version of the questionnaire was used each year, but questions about principal shopping destinations and on alternative ways of food provisioning remained the same during the three waves of the survey. The same structure applied to a range of questions about the respondent's basic characteristics and there were no significant differences in terms of broad demographic characteristics between the three waves. It was therefore possible to merge the three datasets for each year based on the same set of questions and indicators.

Regrettably, there is no information on the shopping motivations and consumer attitudes of the respondents. Therefore, the analysis presented here is methodologically closer to a geodemographic approach, since there are responses to the primary shopping destination and some alternatives in food shopping, as well as an array of demographic, socio-economic, geographic and some psychographic variables for the respondents.

The key questions posed were as follows:

- "In what type of retail outlet do you mostly shop for food?" (possible responses: hypermarket, supermarket, discount store; smaller self-service shop; convenience shop/Asian convenience shop; small counter shop; other; does not shop for food); and

- "Do you, at least occasionally, acquire food by any of these forms?" (possible responses coded as "yes" or "no" for the following: shopping at farmers' markets; ordering of boxes in a box scheme; direct on-farm sale; shopping in farmers' shops; self-provisioning; foraging).

The characterising variables used for classifications and other analyses were: age, gender, education, occupation, family status, household size, number of children, household income, personal income, place of residence, type of residential area, type of housing, etc.

Statistical analysis was carried out using SPSS (version 20.0). The results were obtained mainly by descriptive statistics and testing hypotheses of similarities or differences of given shopper populations by contingency analysis. For associations between dependent variables and shopper characteristics, the calculation of contingency coefficients (CC) was applied.

Altogether (over the three waves), the sample comprised 3,168 respondents, $48.8 \%$ of whom were male and $51.2 \%$ were female. The mean age was 46.6 years (SD 17.1). Almost six of ten (59.4\%) respondents were economically active and $40.6 \%$ economically inactive. The largest group of respondents $(27.3 \%)$ were regular employees, $10.3 \%$ were individual entrepreneurs and $24.5 \%$ were retired. Slightly more than one-third $(35.3 \%)$ of the respondents had attained secondary education without a graduation exam and vocational training, 32.8\% had secondary education with graduation exam, $16 \%$ had finished some level of tertiary education, and $15.8 \%$ had received only an elementary education. Half of the respondents were married or in a partnership, $28 \%$ were single, $12.7 \%$ were divorced and 8.5 were widowed. Around one third of the respondents lived in a housing estate $(32.8 \%), 28.5 \%$ lived in a family house, $18.6 \%$ in an apartment and $15.3 \%$ lived in a terraced house. Most of the respondent households had two members $(35.8 \%), 21.2 \%$ of the households had three members, $19.4 \%$ four members and $18.3 \%$ were single households. Over two-thirds $(68 \%)$ of the families were without children under 18 years, and families with children had mostly one (15.9\%) or two children $(13.4 \%)$ under 18 years. 
The responses regarding the main shopping place are presented in Table 1. It is obvious that most of the respondents prefer large-scale retail outlets such as hypermarkets, supermarkets and discount stores. About one fifth of the respondents use smaller self-service shops, and the remainder of the retail formats (as presented) has a much lower patronage (around 3\% of the respondents).

Table 2 shows the occurrence of alternative types of shopping for food and food provisioning. More than half of the respondents (58\%) have some experience with foraging, and a high percentage of them $(45.8 \%)$ also use some self-provisioning when acquiring their food. As regards the alternative food networks, the most popular form are the farmers' markets $(37.5 \%$ of the respondents do sometimes shop there) and direct shopping at the farm gate (23\% of respondents). Farmer shops are used by almost 18\% of respondents and box schemes are utilised by $4.6 \%$ of respondents.

\section{Results and discussion}

In the results section the various shopping formats will be discussed and their patrons will be characterised. In further analysis, the respondents who indicated that they do not shop for food or chose "other" as their shopping place, will be excluded from the discussion of results. Also, the shoppers who responded that they are involved in selfprovisioning and foraging are not analysed further as these forms of food provisioning do not fall under the category of

\begin{tabular}{lrr}
\hline Shopping place for food & \multicolumn{1}{c}{ n } & \multicolumn{1}{c}{$\%$} \\
\hline hypermarket, supermarket, discount store & 2,214 & 70.0 \\
smaller self-service shop & 649 & 20.5 \\
convenience shop/Asian convenience shop & 91 & 2.9 \\
small counter shop & 105 & 3.3 \\
other & 10 & 0.3 \\
does not shop for food & 93 & 2.9 \\
total & $\mathbf{3 , 1 6 2}$ & $\mathbf{1 0 0 . 0}$ \\
\hline
\end{tabular}

Tab. 1: Main shopping place of respondents (valid responses). Source: CVVM 2014, 2015, 2017

\begin{tabular}{lcrr}
\hline $\begin{array}{l}\text { Alternative types of shopping } \\
\text { and food provisioning }\end{array}$ & & n & $\%$ \\
\hline farmers' market & yes & 1,185 & 37.5 \\
box scheme & no & 1,979 & 62.5 \\
\multirow{2}{*}{ on farm } & yes & 146 & 4.6 \\
& no & 3,017 & 95.4 \\
farmer shop & yes & 729 & 23.0 \\
& no & 2,435 & 77.0 \\
self-provisioning & yes & 565 & 17.9 \\
& no & 2,598 & 82.1 \\
foraging & yes & 1,448 & 45.8 \\
& no & 1,716 & 54.2 \\
& yes & 1,834 & 58.0 \\
& no & 1,329 & 42.0 \\
\hline
\end{tabular}

Tab. 2: Alternative types of shopping reported by respondents (valid responses).

Source: CVVM 2014, 2015, 2017 retail and retailing. The categories of personal income and household income were not included in the first analysis, because a large proportion of respondents refused to answer the questions on their income situation. As a proxy to the socio-economic situation of the respondent, education and occupation are used and understood to be indicative of the individual's financial situation.

\subsection{Large-scale and traditional retail forms and their customers}

Some general characteristics of shoppers in large-scale and traditional formats can be derived from Table 3. Largescale retail outlets have a relatively balanced customer base from the gender point of view. When it comes to age, they are visited mainly by customers in the age range 35-44 years $(20 \%)$ and $25-34$ years $(19.2 \%)$. Their customers are mostly secondary graduated $(35.3 \%)$ or with secondary and vocational training $(34.2 \%)$. These outlets reported the highest percentage of married customers (almost 54\%). They are from households with two $(36.2 \%)$ or three and four members (22.9\%, respectively $20.1 \%$ ) and they are having one (17.5\%) or two (15\%) children up to 18 years. These shoppers lived in housing estates (almost 36\%) or in family houses (26\%).

Smaller self-service shops attract slightly more females than males (56\% versus $44 \%$ ). In terms of age, the customers are mainly those aged over 65 (25.4\%) and aged 55-64 (19.9\%). Most of their customers had a secondary education without graduation (39\%). They were mostly married (45.7\%), single (27.8\%) or widowed (14.8\%). They came from two member or single households (37\%, respectively 24\%), predominantly without small children (76.4\%). They lived mainly in single family houses (34\%) or housing estates (25\%).

Convenience, or Asian convenience shops, had a predominantly male customer base (68\%). In terms of age, their customers are recruited from the age groups 25-34 (23.1\%), and 18-24 (19.8\%). The education of their shoppers is mainly elementary $(31.1 \%)$ and secondary or vocational (25.6\%). Single people represented $46.2 \%$ of the convenience shops customers. They came mostly from two-person households $(31.1 \%)$ or three-person households (26.7\%) and having most often one child under the age of 18 (17.6\%). As regards the type of dwelling, these customers live mostly in housing estates $(35.1 \%)$ or family houses $(31.6 \%)$.

Small counter shop customers were predominantly male (59\% versus $41 \%$ female). One third were 65 years and older, but also one fifth of them were middle-aged (19\%: 35-44 years). They mostly had an elementary (32.4\%) or secondary education without graduation $(31.4 \%)$. Their distribution according family status was more equally distributed than in the case of other retail forms under study, with most of them married (39\%) or single (26.7\%). They came from single member or two-member households (37.1\% respectively $28.6 \%$ ). One third of them lived in family houses, followed by terraced houses $(22.7 \%)$ and housing estates $(18.7 \%)$.

An analysis of specific associations between the preferred retail forms and customer characteristics also reveals interesting findings. As already suggested, gender is slightly but significantly associated with a preferred retail format (CC [contingency coefficient] $=0.137, \mathrm{p}<0.001$ ), with significantly more men shopping in convenience and Asian convenience shops than women. Age is also significantly related to a preferred retail format $(C C=0.211, p<0.001)$ : 


\begin{tabular}{|c|c|c|c|c|c|}
\hline \multicolumn{2}{|c|}{ Independent variable } & \multirow{2}{*}{$\begin{array}{c}\begin{array}{c}\text { Hypermarket, } \\
\text { supermarket, } \\
\text { discount store }\end{array} \\
47.7\end{array}$} & \multirow{2}{*}{$\begin{array}{c}\text { Smaller self- } \\
\text { service shop }\end{array}$} & \multirow{2}{*}{$\begin{array}{c}\begin{array}{c}\text { Convenience } \\
\text { shop/Asian } \\
\text { convenience shop }\end{array} \\
68.1\end{array}$} & \multirow{2}{*}{$\begin{array}{c}\begin{array}{c}\text { Small counter } \\
\text { shop }\end{array} \\
59.0\end{array}$} \\
\hline$\ddot{\bar{g}}$ & male & & & & \\
\hline$\stackrel{\vec{D}}{0}$ & female & 52.3 & 55.9 & 31.9 & 41.0 \\
\hline \multirow{6}{*}{ 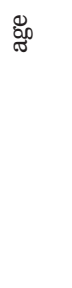 } & $18-24$ & 9.9 & 10.8 & 19.8 & 10.5 \\
\hline & $25-34$ & 19.2 & 16.3 & 23.1 & 12.4 \\
\hline & $35-44$ & 20.0 & 13.7 & 15.4 & 19.0 \\
\hline & $45-54$ & 17.8 & 13.9 & 17.6 & 11.4 \\
\hline & $55-64$ & 16.7 & 19.9 & 13.2 & 13.3 \\
\hline & $65+$ & 16.4 & 25.4 & 11.0 & 33.3 \\
\hline \multirow{4}{*}{ 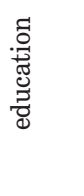 } & elementary & 12.9 & 19.5 & 31.1 & 32.4 \\
\hline & secondary w/o graduation, vocational & 34.2 & 38.9 & 35.6 & 31.4 \\
\hline & secondary with graduation & 35.3 & 28.3 & 25.6 & 23.8 \\
\hline & tertiary & 17.6 & 13.3 & 7.8 & 12.4 \\
\hline \multirow{4}{*}{ 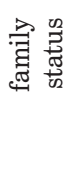 } & single & 26.8 & 27.8 & 46.2 & 26.7 \\
\hline & married & 53.9 & 45.7 & 25.3 & 39.0 \\
\hline & divorced & 13.0 & 11.7 & 17.6 & 18.1 \\
\hline & widowed & 6.4 & 14.8 & 11.0 & 16.2 \\
\hline \multirow{5}{*}{ 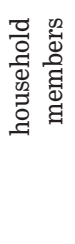 } & 1 & 15.9 & 24.1 & 25.6 & 37.1 \\
\hline & 2 & 36.2 & 37.1 & 31.1 & 28.6 \\
\hline & 3 & 22.9 & 15.9 & 26.7 & 10.5 \\
\hline & 4 & 20.1 & 16.8 & 14.4 & 14.3 \\
\hline & 5 and more & 5.0 & 6.1 & 2.2 & 9.6 \\
\hline \multirow{5}{*}{ 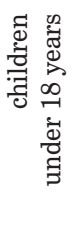 } & 1 & 17.5 & 11.6 & 17.6 & 10.5 \\
\hline & 2 & 15.0 & 9.8 & 8.8 & 9.5 \\
\hline & 3 & 2.4 & 2.0 & 1.1 & 3.8 \\
\hline & 4 and more & 0.5 & 0.2 & 0.2 & 1.0 \\
\hline & no children under 18 years & 64.5 & 76.4 & 70.3 & 75.2 \\
\hline \multirow{6}{*}{ 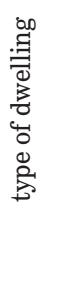 } & apartment house & 19.6 & 16.2 & 21.1 & 13.3 \\
\hline & housing estate & 35.9 & 25.2 & 35.1 & 18.7 \\
\hline & residential house & 2.7 & 2.0 & 3.5 & 4.0 \\
\hline & terraced house & 13.9 & 19.8 & 7.0 & 22.7 \\
\hline & family house & 26.1 & 33.9 & 31.6 & 33.3 \\
\hline & other & 1.8 & 2.9 & 1.8 & 8.0 \\
\hline
\end{tabular}

Tab. 3: Basic characteristics of customers in large-scale and traditional formats (relative frequencies by various retail formats). Source: CVVM 2014, 2015, 2017; author's calculations

significant residuals (differences between observed and expected frequencies) are reported in the cases of younger people (18-24 years) shopping significantly more often in convenience shops, while older people $(65+)$ prefer the smaller self-service shops and small counter stores, avoiding large-scale retail formats, and the middle-aged group of 35-44 years who shop significantly more often in large-scale retail formats and less often in smaller self-service shops.

Education is another significant factor with the preferred shopping place $(C C=0.170, p<0.001)$. Significantly more people with only an elementary education use small counter shops and convenience shops, as well as small self-service shops. These findings correspond with previous surveys of shoppers (Spilková, 2012b), which showed that smaller selfservice shops are chosen more often by people with lower education and lower incomes. In contrast, significantly more people with a secondary education with graduation and tertiary education, shop for food in large-scale outlets. The association between shopping place and family status also shows significant results $(\mathrm{CC}=0.184, \mathrm{p}<0.001)$, documenting the fact that married people significantly prefer large-scale retail formats to the other types of shopping venues; singles, on the contrary, have greater standardised residuals in the case of convenience or Asian convenience shops (which are largely avoided by married respondents). Widows and widowers have significantly more preference for small self-service shops and small counter shops. Family situation is also reflected in the results for family size and number of children under $18(\mathrm{CC}=0.201, \mathrm{p}<0.001$, respectively $\mathrm{CC}=0.140, \mathrm{p}<0.001$ ), again demonstrating that single households significantly prefer small counter shops and smaller self-service shops and avoid large-scale formats, and families with children prefer large-scale formats and avoid smaller self-service shops. 
These results also confirm some previous findings from the monitoring of shoppers (Spilková, 2012b), which showed that hypermarkets are preferred by more educated people and shoppers from families with children. Occupation is also significantly related to preferred shopping format $(\mathrm{CC}=0.270, \mathrm{p}<0.001)$, with interesting results gained from the residuals analysis. Pensioners have a strong preference for small self-service shops and small counter shops and significantly more often avoid large-scale formats. In contrast, large-scale outlets are the preferred destinations for persons in managerial positions and general employees. Both of these labour groups, as well as entrepreneurs, avoid smaller self-service shops. Unemployed people quite clearly prefer convenience or Asian convenience shops and small counter shops. The preferred shopping format also relates to the type of dwelling $(\mathrm{CC}=0.208, \mathrm{p}<0.001)$, with significantly more people from housing estates shopping in large-scale outlets and avoiding smaller self-service shops and small counter shops, and small self-service shops being more often preferred by people from both terraced and individual family houses.

Another step in the analysis is the geographical perspective. Geography, obviously, influences the potential clientele of various retail formats with respect to the distribution of shopping opportunities and the structure of the population. As Table 4 shows, large-scale format customers are scarce only in the smallest villages, but their distribution in settlements above five thousand inhabitants is quite even. This is the result of the deconcentrating strategies of foreign retailers in the Czech Republic. As the largest Czech cities became saturated by large-scale retail formats, the focus of new development shifted into smaller cities. These locations have witnessed the emergence of new retail formats - smaller hypermarkets and smaller shopping centres appropriate to the size and purchasing power of the non-metropolitan area population. These "smaller versions" of hypermarkets were soon followed by discount store chains, competing successfully for the first-comers and gaining in popularity since about 2003 (Spilková, 2012b). In contrast, smaller self-service shops and convenience shops are typical for the smallest and smaller settlements (800-14,999 inhabitants) and then decline in patronage for the larger cities. They are traditionally used by customers in settlements where the offer of other retail formats is limited (Spilková, 2012b). Small counter shops again evince a dichotomy: their patronage gradually decreases from the smallest villages to cities with populations of around 80,000. This decline obviously describes the situation of small counter shops serving convenience shopping purposes. The higher proportion of their customers reappears again in the category of cities with over 80,000 inhabitants and the larger cities, where they are more likely to be small specialist stores with a niche clientele. This relation between the main shopping place and size of residence is also documented by a statistically significant result of contingency analysis $(\mathrm{CC}=0.303, \mathrm{p}<0.001)$.

Figure 1 depicts the distribution of the main shopping place formats in Czech regions. The large-scale formats prevail in all Czech regions, but their position is far stronger in the capital city and the north-western part of the country. North-western Bohemia is also that part of the country with important percentages of shoppers in convenience and Asian convenience shops, which on the contrary, are quite insignificant in the Vysočina region and Moravia. The proportion of smaller self-service shops and small counter shops also has a clear west-east gradient. The association between the main shopping place and region is statistically significant $(\mathrm{CC}=0.252, \mathrm{p}<0.001)$, showing significant positive residuals (a significantly higher proportion than would be expected) for customers of largescale retail formats in Prague and the Ústí nad Labem region, for customers of smaller self-service shops in Plzeň, Pardubice, Vysočina and the Southern Moravian region, for convenience shop customers in Plzeň, Karlovy Vary and the Ústí nad Labem region, and for small counter shops in the Moravian-Silesian region.

\subsection{Alternative food networks and their customers}

Table 5 depicts the basic characteristics of customers with some experience of alternative ways of food shopping. At first glance, the differences may not be as obvious as in the case of large-scale and traditional retail formats. Farmers' markets are more often used by women (59\%). Their customers are younger and middle-aged (20\% in $25-$ 34 years, $21 \%$ in $35-44$ years groups). In terms of education they are mostly with secondary education with graduation or vocational $(35.7 \%$, respectively $31.5 \%)$. As regards the family status, they are mostly married or single $(56 \%$, respectively $23.6 \%$ ), and people from smaller households, with one or two children. Their customers typically live in housing estates $(34.3 \%)$, family houses $(28.3 \%)$ or flats in apartment houses (19.9\%).

Box schemes are a predominantly female format (62.3\%). They are attracting mostly middle-aged customers $(23.3 \%$ in $35-44$ years, $19.9 \%$ in $45-54$ years groups). In terms of

\begin{tabular}{lcccc}
\hline Size of residence & $\begin{array}{c}\text { Hypermarket, } \\
\text { supermarket, } \\
\text { discount store }\end{array}$ & $\begin{array}{c}\text { Smaller self-service } \\
\text { shop }\end{array}$ & $\begin{array}{c}\text { Convenience shop/ } \\
\text { Asian convenience } \\
\text { shop }\end{array}$ & $\begin{array}{c}\text { Small counter } \\
\text { shop }\end{array}$ \\
\hline less than 799 & 7.2 & 13.1 & 4.4 & 32.4 \\
$800-1,999$ & 11.7 & 20.5 & 20.9 & 20.0 \\
$2,000-4,999$ & 8.1 & 20.5 & 23.1 & 10.5 \\
$5,000-14,999$ & 15.4 & 15.6 & 14.3 & 6.7 \\
$15,000-29,999$ & 15.6 & 7.4 & 5.5 & 6.7 \\
$30,000-79,999$ & 12.5 & 6.5 & 6.6 & 2.9 \\
$80,000-999,999$ & 14.3 & 8.5 & 8.8 & 14.3 \\
$1,000,000$ and more & 15.1 & 8.0 & 16.5 & 6.7 \\
\hline
\end{tabular}

Tab. 4: Distribution of responses to the main shopping place with respect to the size of residence (relative frequencies in various retail forms). Source: CVVM 2014, 2015, 2017; author's calculation 


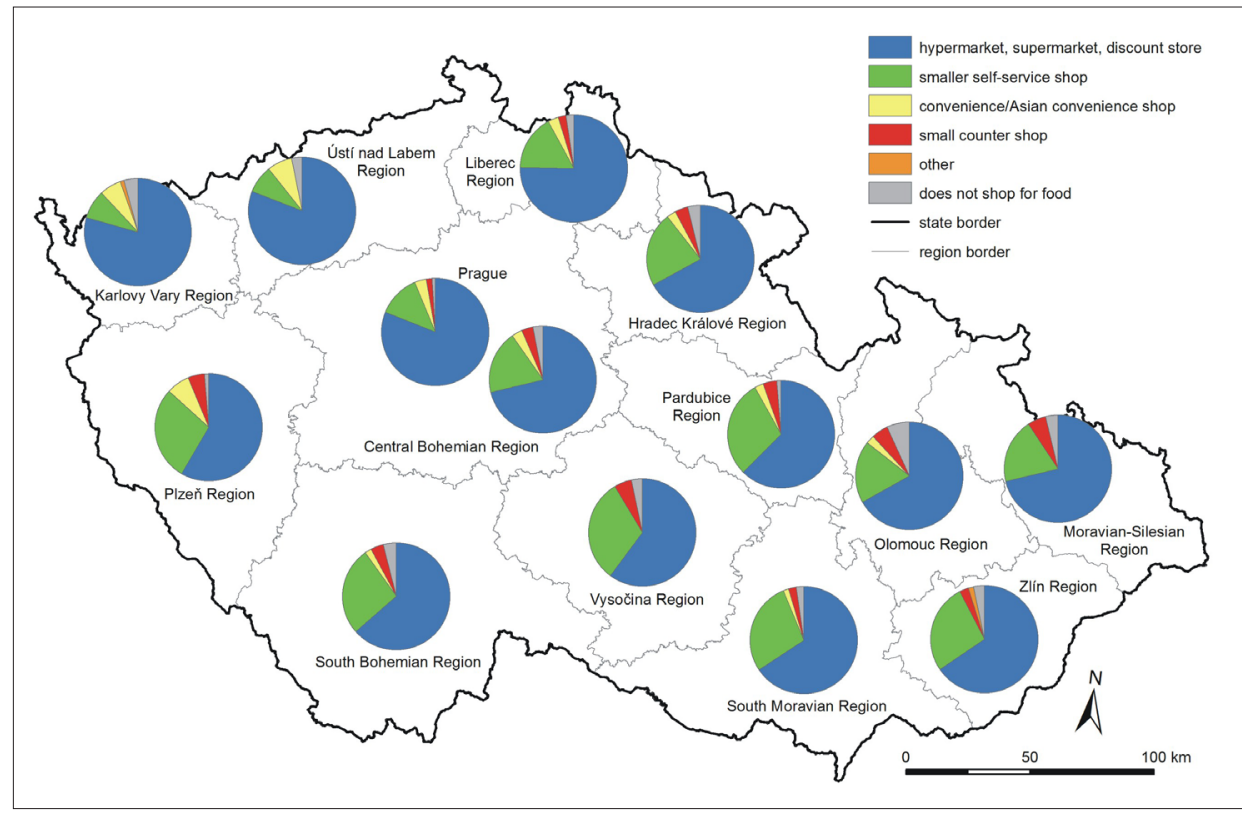

Fig. 1: Main shopping place according to Czech regions Source: CVVM 2014, 2015, 2017; author's calculation

education they are preferred by customers with a secondary education without graduation or with graduation $(38.6 \%$, respectively $33.8 \%$ ). Their families tend to be slightly larger than in the previous case, as well the children in their households are more numerous. People from single family houses prevail (36\%), followed by customers living in flats within housing estates $(25.8 \%)$.

On farm shopping is more gender equal. It is having its supporters both in younger middle-age (22\% in 35-44 years) and in older respondents (19\% in 65+ years). Again, most of the shoppers on farms have a secondary education with or without graduation. In terms of family status, they are predominantly married $(70 \%)$, and from smaller households (37.9\% from two-member households). They are living mostly in a family house $(38.6 \%)$ or housing estate $(26.5 \%)$.

Farmer shop customers are more likely to be women $(57.3 \%)$. As regards their age, they are middle-aged and younger (21.1\% in $35-44$ years, respectively $19.8 \%$ in $25-$ 34 years groups). They tend to have a secondary education with or without graduation, and we also see about a quarter (26.1\%) of farmer shop customers with a university degree. Also, the family structure is more balanced. Although the majority of these shoppers are married (53.4\%), there is a high percentage of singles $(26.4 \%)$ and divorced people (13.5\%). They come from smaller families with one or two children. They live mainly in housing estates or family houses (34.3\%, respectively $24.4 \%$ ).

Again, we continue with an analysis of residuals to uncover where are the largest similarities or differences of given shopper populations according to their characteristics. Shopping at farmers' markets reveals significant associations with gender $(\mathrm{CC}=0.121, \mathrm{p}<0.001)$, with significantly more women shopping there. Such results are typical for studies aimed at farmers' market shoppers elsewhere (Byker et al., 2012; Zepeda, 2009). Also, the association with age is statistically significant $(\mathrm{CC}=0.120$, $\mathrm{p}<0.001$ ), with significantly more customers in the age category of 35-44 years and less in the group of 18-24 years. Education is also significantly associated with shopping at farmers' markets $(\mathrm{CC}=0.194, \mathrm{p}<0.001)$, with a prevailing higher number of customers with a tertiary education. In contrast, these markets are mostly avoided by people with only an elementary education and/or with vocational training. Education was also found to be a key determinant of shopping at farmers' markets in other studies (Byker et al., 2012). This fact is even more accentuated in the analysis of farmers' market patronage and occupation $(\mathrm{CC}=0.218, \mathrm{p}<0.001)$, where managers, entrepreneurs, general employees and mothers on maternity leave have the largest positive residuals for this type of shopping venue, opposed to unemployed people, pensioners and students. Although these results could lead to conclusions of social exclusivity at farmers' markets (Spilková et al., 2013), more detailed surveys aimed not only at shoppers' demographic characteristics but also at their values and motivations would be needed to confirm this statement. Family status also reveals that married people shop at farmers' markets significantly more often than other groups $(\mathrm{CC}=0.097$, $\mathrm{p}<0.001$ ), mostly those having one child in the family $(\mathrm{CC}=0.106, \mathrm{p}<0.001)$. The type of dwelling, however, did not show any significant association with shopping at farmers' markets, which documents the fact that farmers' markets have quickly spread to all regions of the country, both urban and rural (Spilková and Perlín, 2013), and today represent a traditional shopping opportunity for food and fresh local produce, wherever.

Ordering a pre-paid box with food was earlier indicated as the least frequent form of alternative food network in the given sample. As shown in the results from our data, gender plays a key role in the box scheme demographic, $(\mathrm{CC}=0.049, \mathrm{p}<0.05)$ with slightly more women ordering boxes. Occupation is also a factor $(\mathrm{CC}=0.097, \mathrm{p}<0.001)$, with significantly more people in managerial positions and women on maternity leave using box schemes. There is also a weak association with the number of children in the family $(\mathrm{CC}=0.069, \mathrm{p}<0.05)$. These results clearly demonstrate that box schemes above all present a convenient way of shopping for quality food for customers with limited mobility (mothers on maternity leave) or time (managers, larger families) (Spilková and Šifta, 2016; Unčovská, 2011). 


\begin{tabular}{|c|c|c|c|c|c|}
\hline \multicolumn{2}{|c|}{ Independent variable } & \multirow{2}{*}{$\begin{array}{c}\begin{array}{c}\text { Farmers' market } \\
(\mathbf{n}=\mathbf{1 1 8 4})\end{array} \\
41.0\end{array}$} & \multirow{2}{*}{$\begin{array}{c}\begin{array}{c}\text { Box scheme } \\
(\mathbf{n}=\mathbf{1 4 6})\end{array} \\
37.7\end{array}$} & \multirow{2}{*}{$\begin{array}{c}\begin{array}{c}\text { On farm } \\
(\mathbf{n}=\mathbf{7 2 9})\end{array} \\
44.6\end{array}$} & \multirow{2}{*}{$\begin{array}{c}\begin{array}{c}\text { Farmer shop } \\
(\mathbf{n = 5 6 5 )}\end{array} \\
42.7\end{array}$} \\
\hline 安 & male & & & & \\
\hline 峁 & female & 59.0 & 62.3 & 55.4 & 57.3 \\
\hline \multirow{6}{*}{$\underset{\infty}{\infty}$} & $18-24$ & 7.1 & 8.2 & 6.7 & 9.0 \\
\hline & $25-34$ & 20.0 & 18.5 & 18.5 & 19.8 \\
\hline & $35-44$ & 21.0 & 23.3 & 22.0 & 21.1 \\
\hline & $45-54$ & 18.3 & 19.9 & 16.2 & 18.9 \\
\hline & $55-64$ & 16.7 & 16.4 & 17.6 & 16.6 \\
\hline & $65+$ & 16.9 & 13.7 & 19.0 & 14.5 \\
\hline \multirow{4}{*}{ 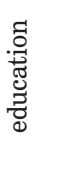 } & elementary & 9.5 & 9.0 & 10.6 & 8.2 \\
\hline & secondary w/o graduation, vocational & 31.5 & 38.6 & 33.7 & 30.6 \\
\hline & secondary with graduation & 35.7 & 33.8 & 34.5 & 35.2 \\
\hline & tertiary & 23.4 & 18.6 & 21.2 & 26.1 \\
\hline \multirow{4}{*}{ 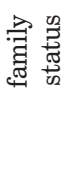 } & single & 23.6 & 21.4 & 21.5 & 26.4 \\
\hline & married & 56.0 & 60.7 & 70.0 & 53.4 \\
\hline & divorced & 13.2 & 10.3 & 9.9 & 13.5 \\
\hline & widowed & 7.1 & 7.6 & 6.6 & 6.7 \\
\hline \multirow{5}{*}{ 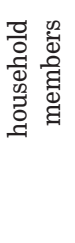 } & 1 & 14.2 & 12.8 & 12.1 & 14.0 \\
\hline & 2 & 38.0 & 30.5 & 37.9 & 35.4 \\
\hline & 3 & 23.2 & 24.1 & 21.9 & 23.1 \\
\hline & 4 & 18.7 & 25.5 & 20.8 & 20.2 \\
\hline & 5 and more & 6.0 & 7.1 & 7.3 & 7.3 \\
\hline \multirow{5}{*}{ 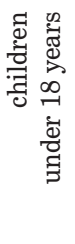 } & 1 & 19.8 & 20.7 & 18.1 & 19.5 \\
\hline & 2 & 15.0 & 20.7 & 17.0 & 15.2 \\
\hline & 3 & 2.9 & 4.1 & 3.3 & 4.6 \\
\hline & 4 and more & 0.4 & 0.7 & 0.7 & 0.5 \\
\hline & no children under 18 years & 61.8 & 53.8 & 60.9 & 60.1 \\
\hline \multirow{6}{*}{ 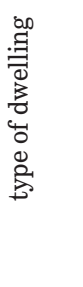 } & apartment house & 19.9 & 14.6 & 14.3 & 15.4 \\
\hline & housing estate & 34.3 & 25.8 & 26.5 & 34.3 \\
\hline & residential house & 2.7 & 6.7 & 2.0 & 3.4 \\
\hline & terraced house & 13.8 & 15.7 & 16.7 & 21.6 \\
\hline & family house & 28.3 & 36.0 & 38.6 & 24.4 \\
\hline & other & 1.0 & 1.1 & 1.8 & 0.8 \\
\hline
\end{tabular}

Tab. 5: Basic characteristics of customers of alternative food networks (relative frequencies by various alternative formats).

Source: CVVM 2014, 2015, 2017; author's calculations

Direct shopping at farms is again significantly related to gender $(\mathrm{CC}=0.047, \mathrm{p}<0.05)$ and age $(\mathrm{CC}=0.086$, $\mathrm{p}<0.001$ ), with women in younger middle-ages $(35-44)$ prevailing. Again, it is preferred mainly by people with a university degree $(\mathrm{CC}=0.102, \mathrm{p}<0.001)$, entrepreneurs, managers and women on maternity leave $(\mathrm{CC}=0.115$, $\mathrm{p}<0.001)$. Family status - being married - is associated with shopping at farms $(\mathrm{CC}=0.126, \mathrm{p}<0.001)$, together with being from a larger household and having two children. As regards the type of living, the association is statistically significant $(\mathrm{CC}=0.146, \mathrm{p}<0.001)$ revealing the largest positive residuals for customers from individual family houses. These results imply that direct shopping at farms is favoured by people who care about the provenance of their food and who also have such opportunities at their disposal and are sufficiently mobile.
Shopping in farmer shops is, unsurprisingly, associated with gender to a slight degree $(\mathrm{CC}=0.058, \mathrm{p}<0.05)$ and age $(\mathrm{CC}=0.072, \mathrm{p}<0.05)$ with significantly less people in the age group $65+$ shopping in farmer shops. This may be caused by the price levels in farmer shops which tend to be higher (Syrovátková, 2016a, b). It is also related to education $(\mathrm{CC}=0.151, \mathrm{p}<0.001)$ where the predominance of tertiary educated customers of farmer shops is especially strong. The exclusivity of shopping in farmer shops is evidenced also by the relation to occupation $(\mathrm{CC}=0.169$, $\mathrm{p}<0.001$ ), as the groups with highest positive residuals are managers and entrepreneurs. It is not associated with family status, although the size of household and a high number of children in the family has some statistical influence $(\mathrm{CC}=0.083, \mathrm{p}<0.05$; respectively $\mathrm{CC}=0.096, \mathrm{p}<0.05)$. Type of dwelling also relates to shopping in farm shops 
$(\mathrm{CC}=0.108, \mathrm{p}<0.05)$ with prevailing shoppers from terraced family houses. All these results support the previous findings of Syrovátková (2016b), who defined farmer shops' customers as those giving priority to quality before price and to a healthy life style (the so-called "foodies").

A geographical analysis of involvement in alternative food networks does not show such a clear picture as in the case of traditional and large-scale formats. Table 6 shows relatively equal distributions of respondents having some experience with shopping in alternative food channels with respect to the size of residence place. Attending farmers' markets is significantly associated with the size of residence $(\mathrm{CC}=0.188, \mathrm{p}<0.001)$, having significantly more shoppers in Prague ( 1 million and more) and in cities with between 15,000 and 29,999 inhabitants. There is also a weak association between box scheme use and residence size $(\mathrm{CC}=0.072, \mathrm{p}<0.05)$, with significantly more customers of box schemes in the smallest villages and then again in the medium-sized cities between 15,000 and 29,999 inhabitants. Shopping directly from farms is also related significantly to size of residence $(\mathrm{CC}=0.128, \mathrm{p}<0.001)$, with the highest positive residuals for shoppers from the smallest villages up to 799 and between 800 and 1,999 inhabitants. Shopping in farmer shops is not significantly associated with size of residence and, as Table 6 shows, farmer shops find their customers equally in almost all the settlement size categories.

Also, the map visualisation in Figure 2 does not show any clear spatial pattern for shoppers in the alternative food networks under study. This is the result of the fact that these networks depend to some extent on the potential of local food production and possibilities of small farmers in

\begin{tabular}{|c|c|c|c|c|}
\hline Size of residence & $\begin{array}{c}\text { Farmers' market } \\
\quad(n=1184)\end{array}$ & $\begin{array}{c}\text { Box scheme } \\
\quad(n=146)\end{array}$ & $\begin{array}{l}\text { On farm } \\
(n=729)\end{array}$ & $\begin{array}{c}\text { Farmer shop } \\
(\mathbf{n}=565)\end{array}$ \\
\hline less than 799 & 6.9 & 16.4 & 13.4 & 9.4 \\
\hline $800-1,999$ & 12.8 & 11.6 & 19.2 & 11.3 \\
\hline $2,000-4,999$ & 6.9 & 8.9 & 10.8 & 10.4 \\
\hline $5,000-14,999$ & 14.3 & 11.6 & 14.5 & 13.6 \\
\hline $15,000-29,999$ & 15.9 & 19.2 & 13.2 & 15.6 \\
\hline $30,000-79,999$ & 11.0 & 9.6 & 8.4 & 10.4 \\
\hline $80,000-999,999$ & 12.8 & 13.0 & 8.9 & 14.3 \\
\hline $1,000,000$ and more & 19.4 & 9.6 & 11.5 & 14.9 \\
\hline
\end{tabular}

Tab. 6: Distribution of responses on shopping in alternative food networks with respect to the size of residence (relative frequencies for alternative retail forms)

Source: CVVM 2014, 2015, 2017; author's calculations

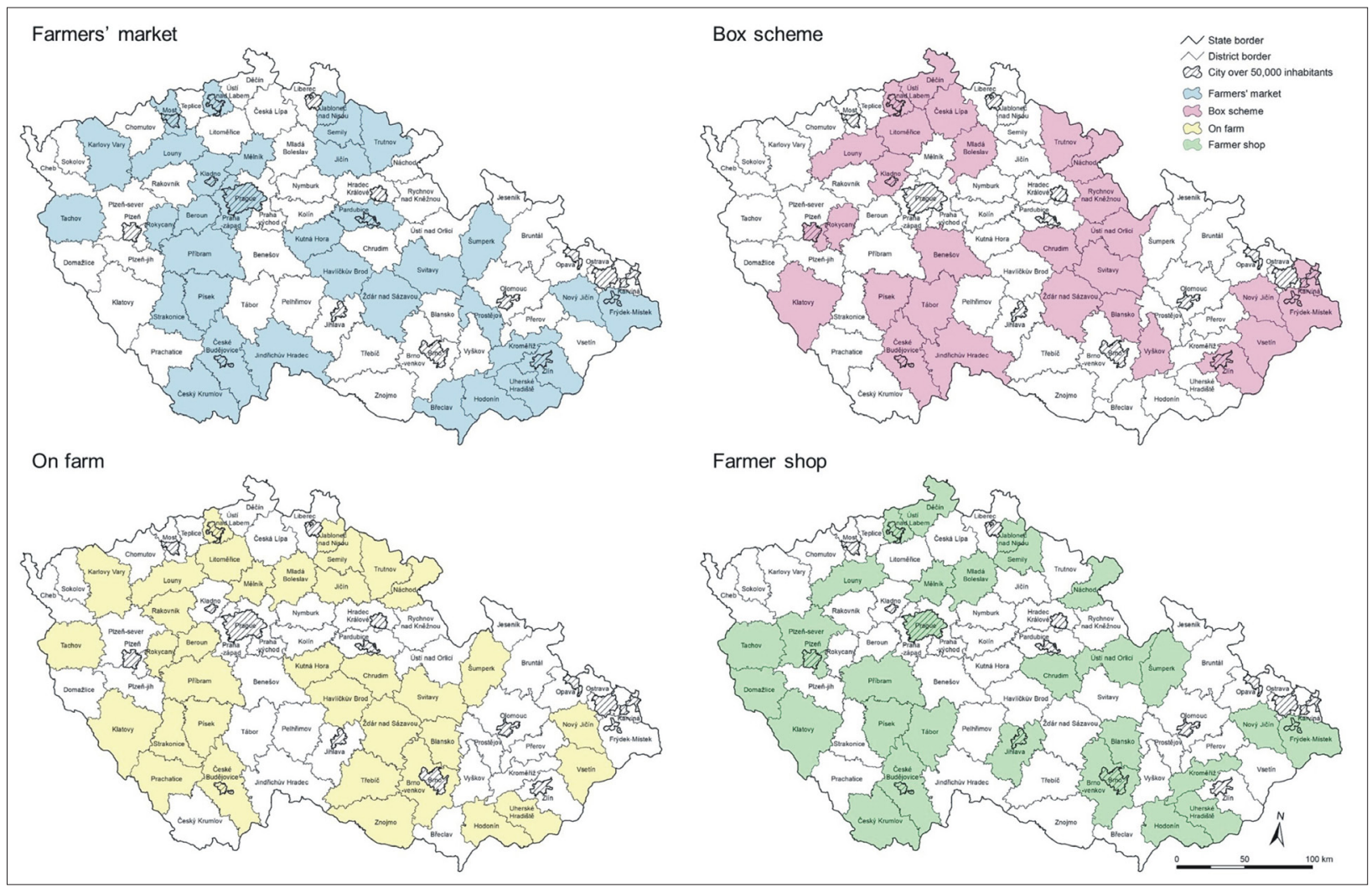

Fig. 2: Alternative food networks - districts with above-average involvement in alternative types of shopping Source: CVVM 2014, 2015, 2017; author's calculations 
particular parts of the country (Syrovátková et al., 2015). Their customers therefore also concentrate in regions where the offer of alternative types of shopping are available and farmers are willing to start these alternatives.

Shopping at farmers' markets relates significantly to region $(\mathrm{CC}=0.176, \mathrm{p}<0.001)$, with a predominance of market shoppers only in Prague and a significant lack of them in the Moravian-Silesian, Olomouc and Karlovy Vary regions. Box schemes also have a statistically significant association with region $(\mathrm{CC}=0.109, \mathrm{p}<0.001)$, with positive residuals for Pardubice and Ústí nad Labem regions. Shopping directly at the farm's gate shows higher residuals only in the South Moravian region $(\mathrm{CC}=0.100, \mathrm{p}<0.05)$ and farmer shops in the South Bohemian and Plzeň regions.

\section{Conclusions}

The objective of this paper was to characterise shoppers according to traditional, "post-traditional" large-scale and alternative food shopping options. Statistical analyses were carried out to reveal demographic, socio-economic and geographic factors affecting the choice of the main shopping place for food and some alternatives of the food shopping behaviours of Czech consumers. The results show that the large-scale retail forms are used mainly by customers of younger and middle age groups, those with a higher level of education, married persons, those from larger families with small children, respondents in positions of ordinary employees or in managerial positions, those living predominantly in housing estates or family houses, almost anywhere in the country, with a special predominance in Prague and the north-western part of the country. Smaller self-service shops are preferred by older people and pensioners, from small households of two or from single household (e.g. widows and widowers), and those with a lower education than in the previous case, living mainly in family houses of smaller settlements, predominantly in the Plzeňský region, the inner periphery (Vysočina and Pardubice regions) and southern Moravia.

When we move to smaller forms of retail provision, the percentage of male shoppers increases, as well levels of education decrease, and the households are smaller. Convenience shops or specifically Asian convenience shops are a format dominated by younger respondents (under 35 years of age), lower educated men (elementary or vocational), those from smaller households or singles again, often unemployed, and respondents living in smaller settlements, predominantly in north-western Bohemia. Small counter shops, in contrast, represent a retail format with a highly varied customer base. They attract more men than women, however, both in the oldest age group as well as in the middle-aged group, from different family status groups and household sizes. This is probably the result of the fact that in the questionnaire, it was not specified if a traditional, more convenience-type counter shop for quick and incidental shopping or rather a specialised counter shop for specific clientele, was considered. This would imply that the number of older $(65+)$ customers, pensioners and those unemployed from the smallest settlements in the first case, and also the representation of younger, married people with families, from terraced houses and living in the largest cities in the latter case of a counter shop.

Alternative food networks, in general, appear to be preferred by women, highly educated people, in managerial positions or entrepreneurs. There are some differences, however, between the various types of these alternatives. Farmers' markets are patronised by younger customers, married, educated, with children or also singles, especially in Prague. Box schemes are used by slightly older women from larger families with children, and often also by women on maternity leave. Shopping directly from farms is favoured by people in the middle age and older groups, highly educated, married, from households with more children, living in single family houses in smaller villages, especially in Southern Moravia. Farmer shops show some evidence of exclusivity as preferred by younger customers, highly educated, from managerial positions or entrepreneurs, from terraced or single-family houses anywhere where these options are available.

Our results demonstrate that there are significant differences between the customers of diverse retail formats. The analysis also shows that, although the demographic and socio-economic characteristics of shoppers are still important features of their segmentation, their shopping place or alternative possibilities to acquire food are also among the most important distinguishing factors characterising Czech shoppers. Alternative food networks obviously represent a new aspect of shopper behaviour profiling and further research on shopper profiles and typologies should take these options into consideration, together with a full range of possible psychographic and socio-demographic determinants.

\section{Acknowledgement}

This work was supported by the Czech Science Foundation grant "Food and the city: The geography of urban agriculture in the Czech context" [grant number 17-03796S].

\section{References:}

BAKER, D., HAMSHAW, K., KOLODINSKY, J. (2009): Who shops at the market? Using consumer surveys to grow farmers' markets: findings from a regional market in northwestern Vermont. Journal of Extension, 47(6): 1-9.

BLOCH, P. H., RIDGWAY, N. M., DAWSON, S. A. (1994): The shopping mall as consumer habitat. Journal of Retailing, 70(1): 70-71.

BYKER, C., SHANKS, J., MISYAK, S., SERRANO, E. (2012): Characterizing farmers' market shoppers: A literature review. Journal of Hunger and Environmental Nutrition, 7(1): $38-52$

CAREY, L., BELL, P., DUFF, A., SHERIDAN, M., SHIELDS, M. (2011): Farmers' market consumers: A Scottish perspective. International Journal of Consumer Studies, 35(3): 300-306.

CONNER, D., COLASANTI, K., ROSS, R., SMALLEY, S. (2010): Locally grown foods and farmers markets: consumer attitudes and behaviors. Sustainability, 2(3): 742-756.

CULLEN, C. W. (1990): Shopping as Entertainment: Implications for the Shopping Centre Manager. Sterling, University of Sterling, Institute of Retail Studies.

DARDEN, W. R., ASHTON, D. (1975): Psychographic profiles of patronage preference group. Journal of Retailing, 50(4): 99-122.

DARDEN， W. R., REYNOLD, F. D. (1971): Shopping orientations and product usage roles. Journal of Marketing Research, 8(4): 505-508. 
ELEPUA, G., MAZZOCCO, M., GOLDSMITH, P. (2010): Consumer segments in urban and suburban farmers markets. International Food and Agribusiness Management Review, 13(2): 3-14.

FEAGAN, R. B., MORRIS, D. (2009): Consumer quest for embeddedness: A case study of the Brantford Farmers' Market. International Journal of Consumer Studies, 33(3): 235-243.

FINN, A., MCQUITY, S., RIGBY, J. (1994): Residents' acceptance and use of a mega-multi-mall: West Edmonton Mall evidence. International Journal of Research in Marketing, 11(2): 127-144.

FREIDBERG, S. (2004): The ethical complex of corporate food power. Environment and Planning D, 22(4): 513-532.

GFK (2016): Shopping Monitor 2016. Prague, GfK.

GOLLEDGE， R. J., STIMSON， R. J. (1997): Spatial Behavior: A Geographical perspective. New York, The Guilford Press.

GOSS, J. (1995): We know who you are and we know where you live: The instrumental rationality of geodemographic systems. Economic Geography, 71(2): 171-198

HOSPODÁŘSKÉ NOVINY (2016): Česko ovládají hypermarkety. Skončily další stovky malých a středních obchodů [online]. [cit. 2.3.2017]. Available at https://byznys.ihned.cz/c1-65248740-cesko-ovladajihypermarkety-skoncily-dalsi-stovky-malych-a-strednichobchodu

JARRAT, D. G. (1996): A shopper taxonomy for retail strategy development. International Review of Retail, Distribution and Consumer Research 6(2): 196-215.

KOTLER, P. (1965): Behavioural models for analysing buyers. Journal of Marketing, 29: 37-45.

KUNC, J., MARYÁŠ, J., TONEV, P., FRANTÁL, B. SIWEK, T., HALÁS, M., KLAPKA, P., SZCZYRBA, Z., ZUSKÁČOVÁ, V. (2013): Časoprostorové modely nákupního chování české populace. Brno, Masarykova univerzita.

KUNC, J., KRIŽAN, F., BILKOVÁ, K., BARLÍK, P., MARYÁŠ́, J. (2016): Are there differences in the attractiveness of shopping centres? Experience from the Czech and Slovak Republics. Moravian Geographical Reports, 24(1): 27-41.

LESSER, J. A., HUGHES, M. A. (1986): Towards a typology of shoppers. Business horizons, 29(6): 56-62.

MARYÁŠ, J., KUNC, J., TONEV, P., SZCZYRBA, Z. (2014): Shopping and services related travel in the hinterland of Brno: Changes from the socialist period to the present. Moravian Geographical Reports, 22(3): 18-28.

MILLER, D., JACKSON, P., THRIFT, N., HOLBROOK, B., ROWLANDS, M. (1998): Shopping, place and identity. London, Routledge.

MORGAN, K. (2010): Local and green, global and fair: The ethical foodscape and the politics of care. Environment and Planning A, 42(8): 1852-1867.

MOSCHIS, G. P. (1976): Shopping orientations and consumer uses of information. Journal of Retailing, 52(2): $61-70$
O'BRIEN, L. G., HARRIS, F. W. (2013): Retailing: Shopping, society, space ( $9^{\text {th }}$ edition). Milton Park, Routledge.

ROEP, D., WISKERKE, J.S. (2012): On governance, embedding and marketing: reflections on the construction of alternative sustainable food networks. Journal of Agricultural and Environmental Ethics, 25(2): 205-221.

SEYFANG, G. (2003): From Frankenstein foods to veggie box schemes: Sustainable consumption in cultural perspective. CSERGE Working Paper EDM 03-13. Norwich: The Centre for Social and Economic Research on the Global Environment, University of East Anglia [online]. [cit. 10.4.2015]. Available at: http://www.cserge. ac.uk/sites/default/files/edm_2003_13.pdf

SINHA, P. K., UNIYAL, D. P. (2005): Using observational research for behavioural segmentation of shoppers. Journal of Retailing and Consumer Services, 12(1): $35-48$

STEPHEN, P. R., WILLET, R.P. (1969): Analysis of consumers' retail patronage strategies. In: McDonald, P. R. [ed.]: Marketing Involvement in Society and The Economy (pp. 316-322). Chicago, AMA.

STONE, G. P. (1954): City shoppers and urban identification: observations on the social psychology of urban life. American Journal of Sociology, 60(1): 36-45.

SPILKOVÁ, J. (2008): Changing face of the Czech retailing in post-communist transformation: risks of extreme polarisation under globalisation pressures. In: Dostál, P. [ed.]: Evolution of Geographical Systems and Risk Processes in the Global Context (pp. 157-171). Prague, P3K.

SPILKOVÁ, J. (2012a): The birth of the Czech mall enthusiast: The transition of shopping habits from utilitarian to leisure shopping. Geografie - Sborník ČGS, 117(1): 21-32.

SPILKOVÁ, J. (2012b): Geografie maloobchodu a spotřeby: věda o nakupování. Prague, Karolinum.

SPILKOVÁ, J. (2016): Alternativní potravinové sítě: Česká cesta. Prague, Karolinum.

SPILKOVÁ, J., FENDRYCHOVÁ, L., SYROVÁTKOVÁ, M. (2013): Farmers' markets in Prague: A new challenge within the urban shoppingscape. Agriculture and Human Values, 30(2): 179-191.

SPILKOVÁ, J., PERLÍN, R. (2013): Farmers' markets in Czechia: risks and possibilities. Journal of Rural Studies, 32(10): 220-229.

SPILKOVÁ, J., RADOVÁ, L. (2011): The Formation of Identity in Teenage Mall Microculture: A Case Study of Teenagers in Czech Malls. Sociologicky časopis/Czech Sociological Review, 47(3): 565-586.

SPILKOVÁ, J., ŠIFTA, M. (2016): Bedýnková schémata: z vidlí na vidličku, tentokrát přes bedničku. In: Spilková, J. [ed.]: Alternativní potravinové sítě: česká cesta (pp. 7788). Prague, Karolinum.

SYROVÁTKOVÁ, M. (2016a): The adoption of the local food concept in a post-communist context: Farm shops in Czechia. Norwegian Journal of Geography, 70(1): 24-40. 
SYROVÁTKOVÁ, M. (2016b): Farmářské obchody: expanze nebo ztráta autenticity alternativních potravinových sítí? In: Spilková, J. [ed.]: Alternativní potravinové sítě: česká cesta (pp. 43-60). Prague, Karolinum.

SYROVÁTKOVÁ, M., HRABÁK, J., SPILKOVÁ, J. (2015): Farmers' markets' locavore challenge: The potential of local food production for newly emerged farmers' markets in Czechia. Renewable Agriculture and Food Systems, 30(4): 305-317.

THOM, A., CONRADIE, B. (2003): Urban agriculture's enterprise potential: Exploring vegetable box schemes in Cape Town. Agrekon, 52(1): 64-86.
UNČOVSKÁ, J. (2011): Bio-bedýnky versus bio-košíky: charakteristiky spotřebitelů biopotravin. Diplomová práce. Brno, Masarykova Univerzita, Fakulta sociálních studií, katedra environmentálních studií.

WILliAMS, R. H., PAINTER, J. J., NICHOLAS, H. R. (1978): A policy-oriented typology of grocery shoppers. Journal of Retailing, 54(1): 21-42.

ZEPEDA, L. (2009): Which little piggy goes to market? Characteristics of US farmers' market shoppers. International Journal of Consumer Studies, 33(3): 250-257.

\section{Please cite this article as:}

SPILKOVÁ, J. (2018): “Tell me where you shop, and I will tell you who you are": Czech shopper profiles according to traditional, large-scale and alternative retail options. Moravian Geographical Reports, 26(3): 186-198. Doi: 10.2478/mgr-2018-0015. 